\section{CORRELATION BETWEEN LEVEL OF DEFENSE AGAINST ACTIVE OXYGEN \\ IN ESCHERICHIA COLI K12 AND RESISTANCE TO BLEOMYCIN}

Sir :

Bleomycin (BLM), which was discovered by UMEZAWA et al. ${ }^{1)}$ has been used in cancer treatment. Biochemical evidences have suggested that double strand scission of cellular deoxyribonucleic acid probably accounts for cytotoxic activities of this antibiotic ${ }^{2)}$. Recently, BLM$\mathrm{Fe}(\mathrm{III})-\mathrm{O}_{2} \mathrm{H}^{-}$[or $\mathrm{BLM}-\mathrm{Fe}(\mathrm{III})-\mathrm{O}_{2}{ }^{2}{ }^{-}$] was reported to be the active form in the reaction with DNA $^{3)}$. Before this reporting, there have been some discrepancies among the data on the action of superoxide dismutase (SOD) in inhibiting DNA fragmentation by $\mathrm{BLM}^{4 \sim 7)}$.

It has been reported that paraquat $\left(1,1^{\prime}\right.$ dimethyl-4,4'-bipyridinium dichloride) increases the rate of biosynthesis of superoxide dismutase in E. coli grown aerobically and lowers the lethal effect of antibiotics producing oxygen radicals $^{8)}$. As we reported previously ${ }^{9)}$, and we also report in next paper, it seems that paraquat increase the defensing activities against active oxygen species such as singlet oxygen. We thought that to test the effect of paraquat would provide an important basis to confirm the involvement of oxygen radicals in the action of BLM.

In the present paper, we report that the treatment of cells of E. coli $\mathrm{K} 12$ with paraquat increases resistance to BLM and the level of defensing activities against active oxygen species.

Glucose minimal medium was consisted of $0.2 \mathrm{~g}$ of $\mathrm{MgSO}_{4} \cdot 7 \mathrm{H}_{2} \mathrm{O}, 2.0 \mathrm{~g}$ of citric acid $\cdot \mathrm{H}_{2} \mathrm{O}$, $10 \mathrm{~g}$ of $\mathrm{K}_{2} \mathrm{HPO}_{4}, 3.5 \mathrm{~g}$ of $\mathrm{NaNH}_{4} \mathrm{HPO}_{4} \cdot 4 \mathrm{H}_{2} \mathrm{O}$, and $5 \mathrm{~g}$ of glucose in 1 liter of distilled water. Trypticase soy-yeast extract (TSY) medium contained $30 \mathrm{~g}$ of Trypticase soy broth (BBL) and $5 \mathrm{~g}$ of yeast extract (Oriental) in 1 liter of distilled water. Incubation of $E$. coli $\mathrm{K} 12$ was carried out aerobically in $10 \mathrm{ml}$ of medium contained in $30 \mathrm{ml} \mathrm{L}$-shaped tubes with shaking at $37^{\circ} \mathrm{C}$, and the growth was monitored by measuring of the optical density at $660 \mathrm{~nm}$. Paraquat (Sigma) was added to the medium by dilution from germfree stock solution prepared by filtration with Millipore filter $(0.22 \mu \mathrm{m})$.

Assessments of resistance towards bleomycin $\mathrm{A}_{2}$ was performed as follows: E. coli $\mathrm{K} 12$, taken from logarithmic phase of growth in glucose minimal medium, was transferred to TSY medium containing $0.0,0.1$ and $1.0 \mathrm{~mm}$ paraquat. After 2 hours of growth in TSY media containing paraquat, the cells were collected by centrifugation at $8^{\circ} \mathrm{C}$ and were washed twice with cold TSY medium and once with glucose minimal medium followed by incubation for 90 minutes in ice-cold glucose minimal medium to remove a residual paraquat from the cells by diffusion. The washed cells were again collected by centrifugation, diluted to $10^{7}$ cells $/ \mathrm{ml}$ in glucose minimal medium in L-shaped tube containing $50 \mu \mathrm{g} /$ $\mathrm{ml}$ bleomycin $\mathrm{A}_{2}$ and $500 \mu \mathrm{g} / \mathrm{ml}$ chloramphenicol, which was added to prevent the subsequent induction of SOD, peroxidase, and catalase during the incubation, and incubated at $37^{\circ} \mathrm{C}$ on a shaker at $200 \mathrm{rpm}$. At indicated intervals samples were taken, appropriately diluted with physiological saline, and plated on TSY medium solidified with $2 \%$ agar for assay of survival cells; colonies on the plate were counted under aerobic incubation. The effect of chloramphenicol on the growth was tested by measuring the growth in control without bleomycin $\mathrm{A}_{2}$.

Cell-free extracts were prepared as follows: cells, which was exposed to $0.0,0.1$, and $1.0 \mathrm{~mm}$ paraquat in TSY medium and thereafter throughly washed to make free of paraquat, were collected by centrifugation at $8,000 \times g$ for 15 minutes at $4^{\circ} \mathrm{C}$ and were washed with $0.1 \mathrm{M}$ potassium phosphate buffer $(\mathrm{pH} 7.0)$. The washed cells were suspended in $50 \mathrm{~mm}$ potassium phosphate buffer ( $\mathrm{pH}$ 7.8) containing $0.1 \mathrm{~mm}$ EDTA and were disrupted for 5 minutes in an ice bath with Tomy Model UR-150P UltraSonifier (operated at an output of $70 \mathrm{~W}$ ). The cell debris was removed by centrifugation at $20,000 \times g$ for 90 minutes and the extract was dialyzed overnight against potassium phosphate EDTA buffer (pH 7.8). The activities of SOD, catalase, and peroxidase of cell-free extracts were measured according to the methods of MCCORD and Fridovich ${ }^{10)}$, BeERs and Sizer ${ }^{11)}$, and Guidotti et al. ${ }^{12)}$, respectively. Singlet oxygen scavenging activity was assayed according to the method, which we report in next paper, based on testing the inhibition of peroxidation of linolenate by singlet oxygen produced photochemically. Protein was estimated by Bio-Rad protein assay method $^{13)}$, using bovine serum albumin as a standard. Bleomycin (copper-free) was sup- 
Fig. 1. Effect of bleomycin $\mathrm{A}_{2}$ on the survival of $E$. coli $\mathrm{K}-12$ grown in the presence or absence of paraquat.

E. coli $\mathrm{K} 12$, which were grown for 2 hours in TSY media containing $0.0,0.1$, and $1.0 \mathrm{~mm}$ paraquat, were collected, washed, and suspended to $10^{7}$ cells $/ \mathrm{ml}$ in glucose minimal medium containing $0.5 \mathrm{mg} / \mathrm{ml}$ of chloramphenicol and $50 \mu \mathrm{g} / \mathrm{ml}$ of bleomycin $\mathrm{A}_{2}$ and were then incubated at $37^{\circ} \mathrm{C}$. At indicated intervals the cells were taken, diluted, and plated onto TSY agar medium, and viable counts were carried out after overnight incubation at $37^{\circ} \mathrm{C}$.

The controls were performed in the same way, but excepting bleomycin $\mathrm{A}_{2}$.

$\square$, Cells grown in the absence of paraquat ( $\mathbf{0}$, control). $\Delta$, cells grown in the presence of $0.1 \mathrm{~mm}$ paraquat ( $\boldsymbol{\Lambda}$, control). $\bigcirc$, cells grown in the presence of $1.0 \mathrm{~mm}$ paraquat ( $\mathrm{e}$, control).

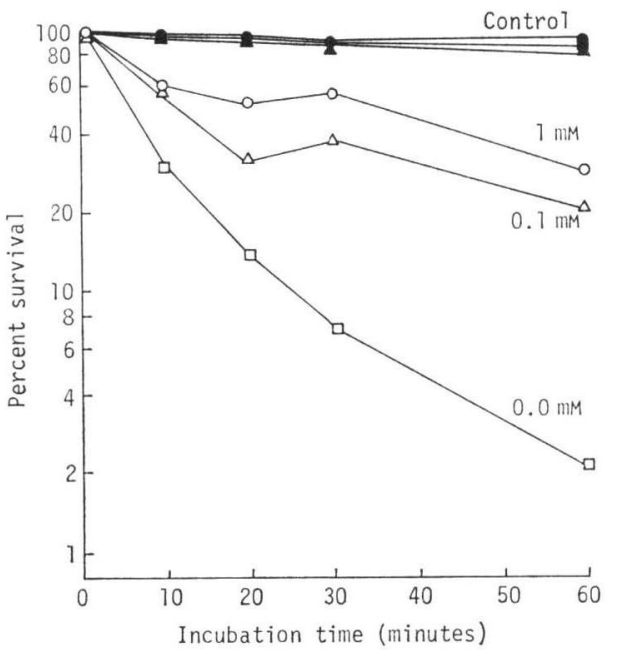

plid by Nippon Kayaku Co. All other chemicals were of reagent grade.

The results, presented in Fig. 1 and Table 1, demonstrated that the prior exposure to paraquat increased cellular levels of defense against active oxygen species and increased resistance towards bleomycin $\mathbf{A}_{2}$. According to the literatures, in vitro DNA chain breakage by $\mathrm{BLM}-\mathrm{Fe}(\mathrm{II})$ is not inhibited by $\mathrm{SOD}^{5,7)}$.

Considering the literature, as discussed in previous and next papers, paraquat treatment increases not only SOD but also the ability to eliminate oxygen radicals. If bleomycin-Fe(III)$\mathrm{O}_{2} \mathrm{H}^{-}$[or BLM-Fe(II)- $\mathrm{O}_{2}{ }^{2-}$ ] is true active form, then this radical may be more rapidly eliminated by paraquat-treated cells, or some mechanisms
Table 1. Effect of paraquat on level of defensing activities against oxygen toxicity.

\begin{tabular}{l|ccc}
\hline \multirow{2}{*}{\multicolumn{1}{c}{ U/mg protein }} & \multicolumn{3}{|c}{$\begin{array}{c}\text { Paraquat } \\
\text { (methyl viologen, mM) }\end{array}$} \\
\cline { 2 - 4 } & 0 & 0.1 & 1.0 \\
\hline Superoxide dismutase & 26.0 & 100 & 155 \\
Catalase & 18.3 & 25.2 & 28.7 \\
Peroxidase & 0.3 & 0.4 & 0.35 \\
Singlet oxygen- & + & ++ & ++++ \\
$\quad$ scavenging activity & & &
\end{tabular}

Activities were measured on the cell-free extracts of $E$. coli $\mathrm{K} 12$, which were grown for 2 hours in TSY media containing $0.0,0.1$ and $1.0 \mathrm{~mm}$ paraquat, according to the methods described in the text.

to produce this bleomycin active form is suppressed in paraquat-treated cells.

\section{Acknowledgement}

This work was supported in part by a Contract NO1-CM-57009 with the Division of Cancer Treatment, National Cancer Institute, U.S.A. and by a Grant-in-Aid for Cancer Research from the Ministry of Education, Science and Culture, Japan.

The authors are gratefully acknowledge Dr. T. TAKITA of our institute for his encouragement and generous supply of bleomycin $\mathbf{A}_{2}$.

\section{Yuzuru Matsuda Mikio KitAhara KENJI MAEDA HAMAO UMEZAWA}

Institute of Microbial Chemistry 3-14-23 Kamiosaki, Shinagawa-ku, Tokyo 141, Japan

(Received March 11, 1982)

\section{References}

1) Umezawa, H.; K. Maeda, T. Takeuchi \& Y. OKAMI: New antibiotics, bleomycin A and B. J. Antibiotics, Ser. A19: 200 209, 1966

2) Suzuki, H.; K. Nagai, H. Yamaki, N. Tanaka \& H. UMEZAWA: On the mechanism of action of bleomycin: Scission of DNA strands in vitro and in vivo. J. Antibiotics 22: 446 448, 1969

3) Kuramochi, H.; K. Takahashi, T. Takita \& H. Umezawa: An active intermediate formed in the reaction of bleomycin-Fe(II) complex with oxygen. J. Antibiotics 34: 576 582, 1981

4) ONISHI, T.; H. Iwata \& Y. TAKAGI: Effects of reducing agents on action of bleomycin. J. 
Biochem. 77: 745 752, 1975

5) IsHIDA, R. \& T. TAKAHASHI: Increased DNA chain breakage by combined action of bleomycin and superoxide radical. Biochem. Biophys. Res. Comm. 66: 1432 1438, 1975

6) Lown, J. W. \& S. Sim: The mechanism of the bleomycin-induced cleavage of DNA. Biochem. Biophys. Res. Comm. 77: 1150 1157, 1977

7) Sausville, E. A.; R. W. Stein, J. A. Peisach \& S. B. Horwitz: Properties and products of the degradation of DNA by bleomycin and iron-(II). Biochemistry 17: 2746 2754, 1978

8) Hassan, H. M. \& I. Fridovich: Regulation of the synthesis of superoxide dismutase in Escherichia coli. J. Biol. Chem. 252: 7667 7672, 1977
9) Matsuda, Y.; M. Kitahara, K. Maeda \& H. UMEZAWA: A method of screening for antibiotics producing oxygen radicals. J. Antibiotics 35: 928 930, 1982

10) McCord, J. M. \& I. Fridovich: Superoxide dismutase: an enzymic function of erythrocuprein. J. Biol. Chem. 244: 6049 6055, 1969

11) BeErs, R. F. \& I. W. Sizer: A spectrophotometric method for measuring the breakdown of hydrogen peroxide by catalase. J. Biol. Chem. 195: $133 \sim 140,1952$

12) Guidott, G.; J. Соцомво \& P. O. FoA: Enzymatic determination of glucose: stabilization of color developed by dianisidine. Anal. Chem. 33: $151 \sim 153,1961$

13) Bio-Rad Laboratories: Instruction Manual for Bio-Rad Protein Assay. 1979 